\title{
Mechanical Properties and Microstructure Evolution of Mg-6 wt \% Zn Alloy during Equal-Channel Angular Pressing
}

\author{
Jingli Yan ${ }^{1,2, *}$, Zijun Qin ${ }^{1}$ and Kai Yan ${ }^{3, *}$ \\ 1 School of Materials Science and Engineering, Southeast University, Nanjing 211189, China; \\ 230059187@seu.edu.cn \\ 2 Jiangsu Key Laboratory for Advanced Metallic Materials, Southeast University, Nanjing 211189, China \\ 3 School of Mechanical Engineering, Yangzhou University, Yangzhou 225009, China \\ * Correspondence: jlyan@seu.edu.cn (J.Y.); yankai@yzu.edu.cn (K.Y.)
}

Received: 17 September 2018; Accepted: 16 October 2018; Published: 18 October 2018

\begin{abstract}
Equal-channel angular pressing (ECAP) was performed on a $\mathrm{Mg}$ (6 wt \%) Zn alloy at temperatures from 160 to $240{ }^{\circ} \mathrm{C}$ and the microstructures and mechanical properties were studied using optical microscopy, X-ray diffraction, scanning electron microscopy, transmission electron microscopy, and an electronic universal testing machine. The results showed that ECAP was effective for grain refinement and a bi-modal grain structure formed at low temperatures, which was stable during ECAP from 160 to $200{ }^{\circ} \mathrm{C} . \mathrm{MgZn}_{2}$ phase and $\mathrm{Mg}_{4} \mathrm{Zn}_{7}$ phase were generated during the ECAP process. The mechanical properties remarkably increased after two repetitions of ECAP. However, the strengths could not be further improved by increasing the plastic deformation, but decreased when ECAP was performed between 200 and $240{ }^{\circ} \mathrm{C}$. The mechanical properties of the ECAP Mg- $6 \mathrm{Zn}$ alloy was determined by a combination of grain refinement strengthening, precipitation hardening, and texture softening.
\end{abstract}

Keywords: Mg-6 wt \% Zn alloy; equal channel angular pressing (ECAP); $\mathrm{MgZn}_{2} ; \mathrm{Mg}_{4} \mathrm{Zn}_{7} ;$ mechanical property; precipitate

\section{Introduction}

As degradable materials, magnesium and its alloys are widely considered as prospective materials in the biomaterials field [1,2]. Compared with traditional metal implant materials and biodegradable polymers, magnesium alloys have excellent performance and function well as medical apparatuses, and thus have promoted the development of new medical products. Many effective alloying elements for $\mathrm{Mg}$ alloys strengthening have to be excluded to avoid the medical risk caused by degradable implants, and only a few elements are sufficiently safe in human bodies, such as zinc. Apart from the required bio-safety, what makes $\mathrm{Mg}-\mathrm{Zn}$-based alloy an important class of biodegradable materials is the good mechanical properties and corrosion resistance [3,4].

As a common severe plastic deformation (SPD) process, equal channel angular pressing (ECAP) is effective for grain refinement of magnesium alloys, which improves the alloys' mechanical properties [5]. For example, a 120\% increase in yield strength and 75\% increase in elongation of ZE41A alloy was achieved after 32 repetitions of the ECAP process [6]. Previous studies on ultra-fined grain (UFG) magnesium alloys prepared by ECAP were mainly concentrated on grain refinement and texture evolution, and the principles of grain refinement and the mechanism of texture evolution were established [7-9]. In the Mg-Zn system, the possible intermetallic phase was hexagonal Laves $\mathrm{MgZn}_{2}$ phase, monoclinic $\mathrm{Mg}_{4} \mathrm{Zn}_{7}$ phase, $\mathrm{MgZn}$ phase, and $\mathrm{Mg}_{7} \mathrm{Zn}_{3}$ phase, depending on the processing conditions [10-12]. However, besides a few early studies on as-cast alloys, research on microstructure 
evolution in $\mathrm{Mg}-\mathrm{Zn}$ alloys using severe plastic deformation or the conventional deformation process is rare.

In the present work, equal-channel angular pressing (ECAP) was performed on a $\mathrm{Mg}(6 \mathrm{wt} \%)-\mathrm{Zn}$ alloy at $160^{\circ} \mathrm{C}, 200^{\circ} \mathrm{C}$, and $240{ }^{\circ} \mathrm{C}$. The mechanical properties during the ECAP process were measured and the precipitation behavior of the alloy during the ECAP process was investigated by analyzing the type and morphology of the intermetallic compounds.

\section{Materials and Methods}

Raw materials of pure metals $\mathrm{Mg}(99.95 \%)$ and $\mathrm{Zn}(99.95 \%)$ were employed to prepare the cast $\mathrm{Mg}$ (6 wt \%)-Zn alloy. The melting process was carried out in an electric resistance furnace under the protection of a mixed gas atmosphere of $\mathrm{SF}_{6}(1 \mathrm{vol} \%)$ and $\mathrm{CO}_{2}(99 \mathrm{vol} \%)$. The melt was held at $680{ }^{\circ} \mathrm{C}$ for $30 \mathrm{~min}$ and then poured into a cylindrical iron mold $60 \mathrm{~mm}$ in diameter. The as-casted billet was extruded into a round bar with a $15 \mathrm{~mm}$ diameter and the extrusion ratio of 16 , and then machined into cylindrical specimens with a diameter of $15 \mathrm{~mm}$ and height of $80 \mathrm{~mm}$.

ECAP, with a 90 degree internal angle between two channels, was performed via route $B_{C}$ (the specimen was rotated $90^{\circ}$ counterclockwise between each pass) [13]. Three levels of experimental temperatures, $160{ }^{\circ} \mathrm{C}, 200{ }^{\circ} \mathrm{C}$, and $240{ }^{\circ} \mathrm{C}$, were selected for the ECAP process. The temperatures were maintained constant within $\pm 1{ }^{\circ} \mathrm{C}$ during ECAP using an automatic temperature controller. ECAP pressing speed was maintained at about $1.5 \mathrm{~mm} / \mathrm{s}$. Before ECAP processing, the samples were put into the ECAP mold that had been heated up to experimental temperature and then the samples were held for at least $5 \mathrm{~min}$. The lubricant during ECAP was a mixture of graphite powder and Vaseline with a mixing ratio of 1:1.

The room temperature tensile test was performed at a speed of $1 \mathrm{~mm} / \mathrm{min}$ using MTS CMT5105 electronic universal testing machine (MTS Systems Corporation, Eden Prairie, MN, USA). Round tension test specimens with diameter of $6.0 \pm 0.1 \mathrm{~mm}$ and gauge length of $30.0 \pm 0.1 \mathrm{~mm}$ were prepared according to ASTM E8M-16a. The mechanical properties were determined on five tension test specimens for each ECAP condition. Microstructural observations of the experimental alloys were carried out via optical microscopy (OM, Leica DMI3000M, Wetzlar, Germany) and a scanning electron microscopy (SEM, Hitachi S-4800II, Hitachi High-Technologies Corporation, Tokyo, Japan). The phase analysis of the alloy was conducted by an X-ray diffractometer (XRD, D8 Advance, Bruker, Billerica, MA, USA) and a field-emission transmission electron microscopy (TEM, Technai G2 20, Field Electron and Ion Company, Hillsboro, OR, USA).

\section{Results}

\subsection{Mechanical Properties}

Figure 1 shows the mechanical properties of $\mathrm{Mg}-6 \mathrm{Zn}$ alloys before and after ECAP processing for two, four, and six repetitions at room temperature. The ECAP temperature is an important factor that affects the mechanical properties of the samples after ECAP. At $160^{\circ} \mathrm{C}$, the strengths increased significantly after ECAP. For instance, the yield strength (YS) and ultimate tensile strength (UTS) increased to $265 \mathrm{MPa}$ and $340 \mathrm{MPa}$, respectively, after two ECAP passes, about $32.5 \%$ and $30.8 \%$ higher than the sample before ECAP. At $200{ }^{\circ} \mathrm{C}$, the YS and UTS were $245 \mathrm{MPa}$ and $274 \mathrm{MPa}$, respectively, after two ECAP passes, both lower than the values at $160^{\circ} \mathrm{C}$. By contrast, a clearly visible decreasing trend in strength was observed in the sample that underwent ECAP at $240{ }^{\circ} \mathrm{C}$. The yield strength of the sample after two passes and six passes of ECAP was $179 \mathrm{MPa}$ and $170 \mathrm{MPa}$, respectively. However, the elongation of the samples for all the two, four, and six passes of ECAP increased with the increase of temperature, as shown in Figure 1c. 
(a)

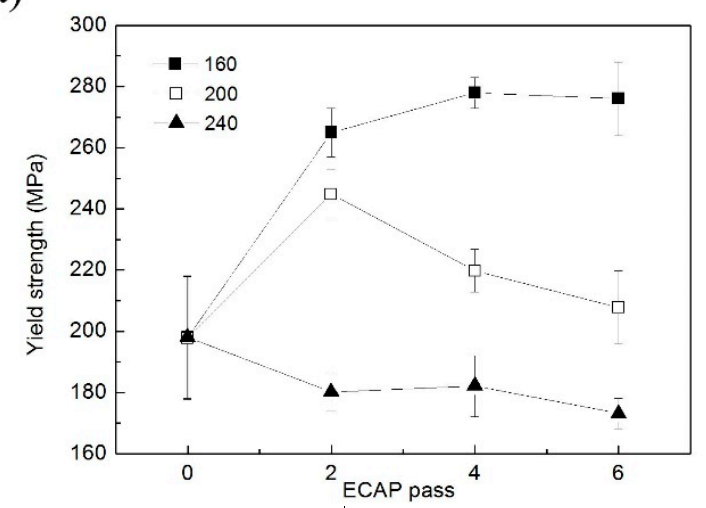

(b)

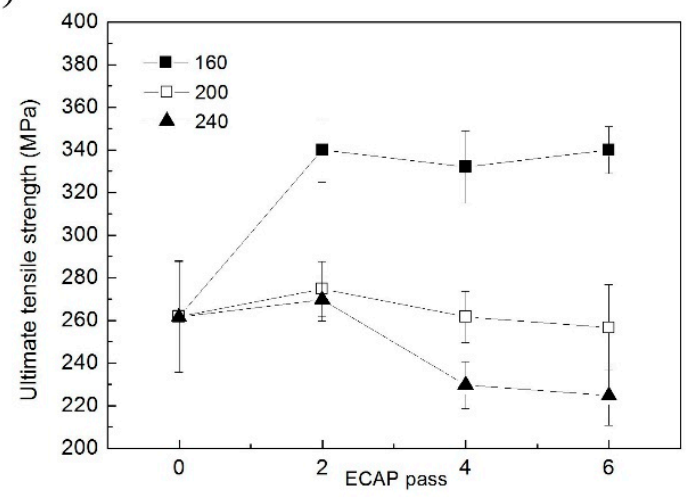

(c)

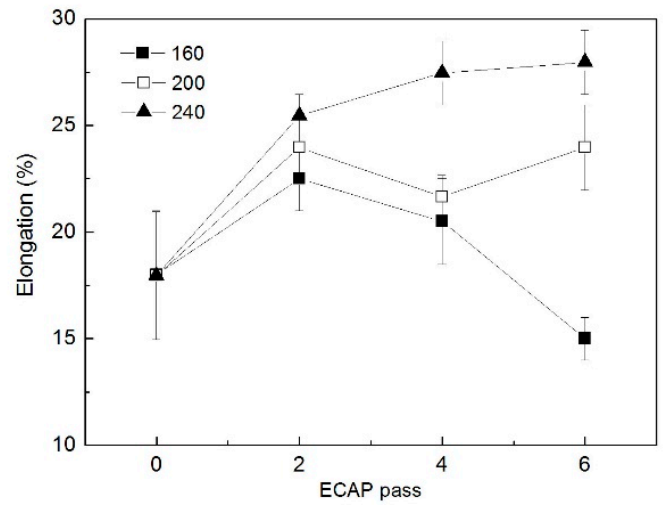

Figure 1. Mechanical properties of Mg-6Zn alloys before and after equal channel angular pressing (ECAP) processing: (a) yield strength, (b) ultimate tensile strength and (c) elongation.

The strengths of the Mg-6Zn alloy did no constantly increase by improving plastic deformation. Both yield strength and ultimate tensile strength were remarkably improved after two passes of $\mathrm{ECAP}$ at $160^{\circ} \mathrm{C}$; however, the strengths were nearly unchanged with further plastic deformation (i.e., four passes and six passes of ECAP processing, as shown in Figure 1b,c). When ECAP processing was performed at $200{ }^{\circ} \mathrm{C}$ and $240{ }^{\circ} \mathrm{C}$, the strengths decreased with increasing numbers of ECAP passes. The elongation of the samples significantly increased after two passes of ECAP at each temperature; however, it decreased with further plastic deformation at $160^{\circ} \mathrm{C}$ but slightly fluctuated at $200{ }^{\circ} \mathrm{C}$ and increased a little at $240{ }^{\circ} \mathrm{C}$.

\subsection{Microstructure}

Figure 2 shows the optical micrographs of the experimental Mg-6Zn alloy, in which the dark contrast phase represents intermetallics. The microstructure of the as-extruded alloy consisted of equiaxed grains with a size of $\sim 15 \mu \mathrm{m}$ and bulk eutectic structure distributed along the grain boundaries. Significant grain refinement and bi-modal grain structure (i.e., comprised of coarse grains and fine grains) were obtained after ECAP for two passes at $160{ }^{\circ} \mathrm{C}$, as shown in Figure $2 \mathrm{~b}$. A heterogenous grain structure was usually produced under the condition of smaller deformation $[14,15]$. When ECAP passes were gradually increased up to six, the average grain size of the larger grains were $\sim 4 \mu \mathrm{m}$ and the grain size of the smaller grains mixed with intermetallic particles was $\sim 1 \mu \mathrm{m}$, as shown in Figure $2 \mathrm{c}$,d. The grain size of the alloy processed by the same ECAP pass increased with increasing ECAP temperature. At $200{ }^{\circ} \mathrm{C}$, the bi-modal grain structure was also observed until the ECAP passes reached six, as shown in Figure $2 \mathrm{e}-\mathrm{g}$. The bi-modal grain structure disappeared when the ECAP temperature was elevated to $240{ }^{\circ} \mathrm{C}$. After two passes of ECAP, 
the microstructure was no more refined but coarsened with increasing numbers of ECAP passes and the average grain size was $\sim 7 \mu \mathrm{m}$ after six passes, as shown in Figure $2 \mathrm{~h}-\mathrm{j}$.
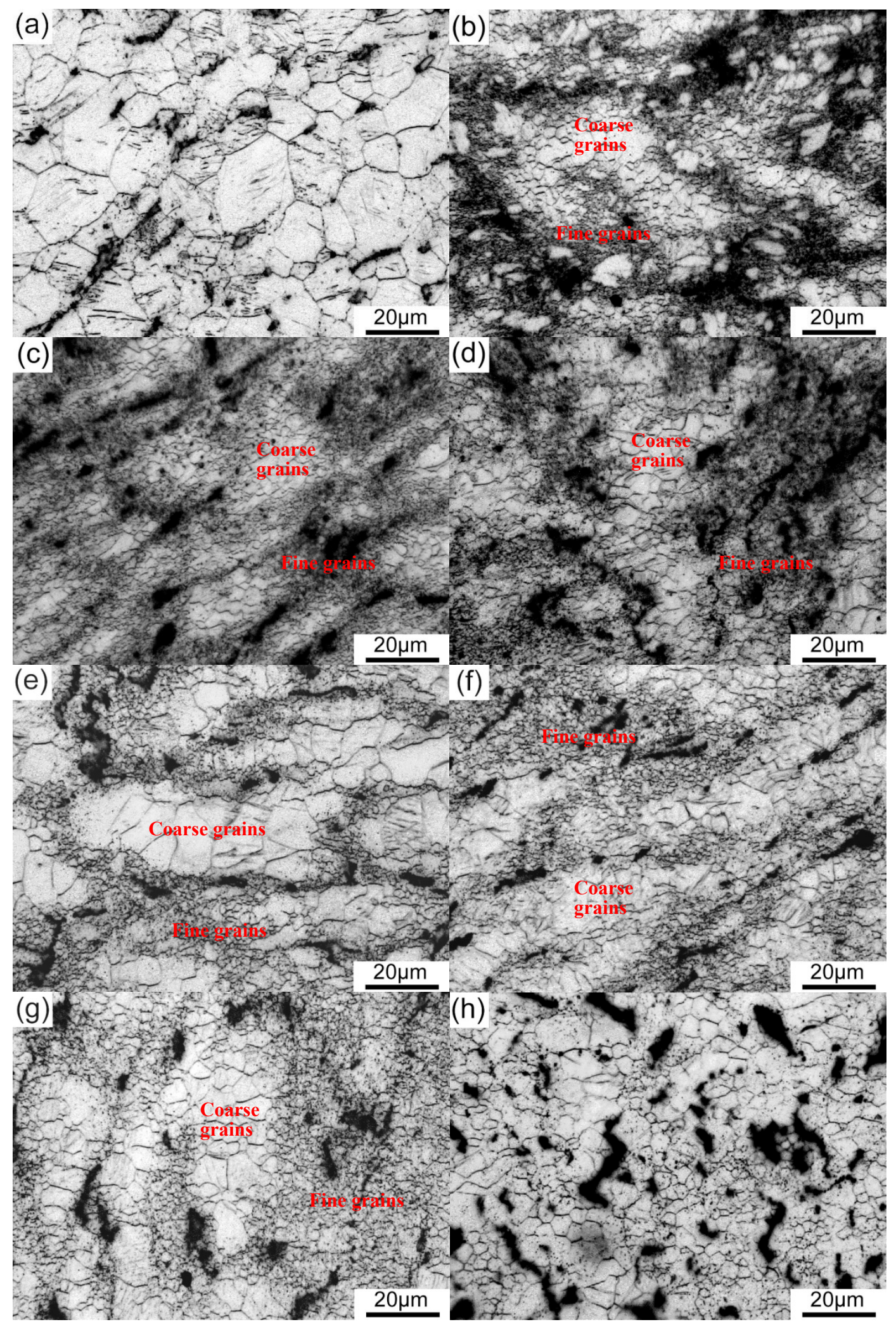

Figure 2. Cont. 


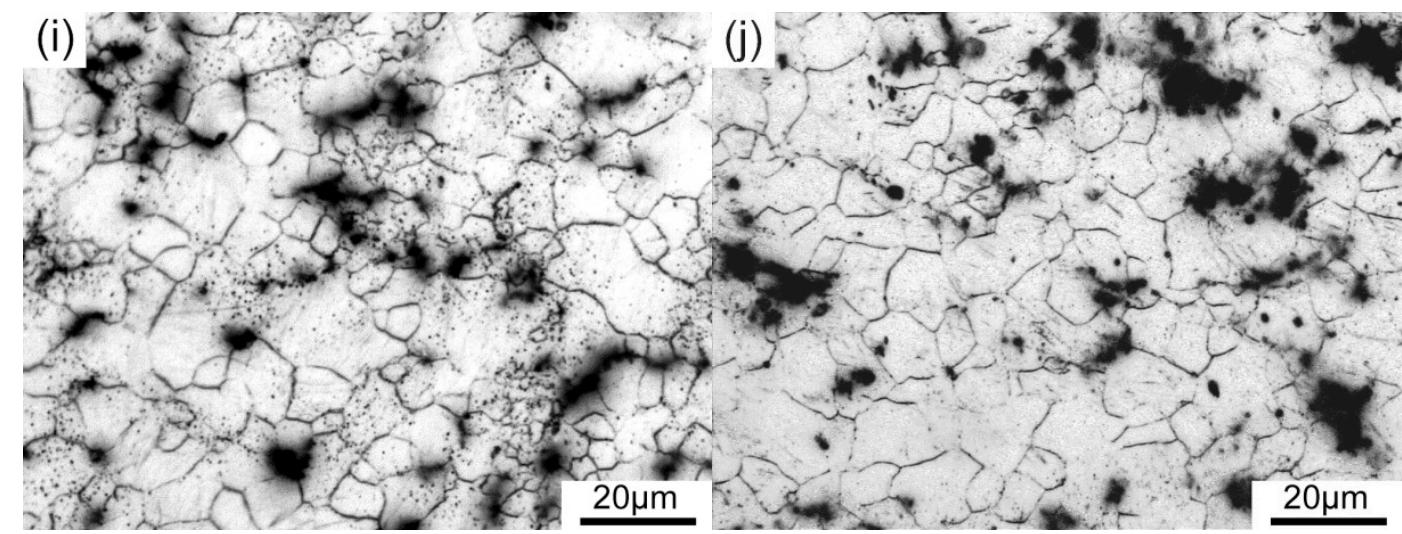

Figure 2. Optical micrographs of Mg-6Zn alloys: (a) as-extruded, and ECAP for (b) two passes at $160{ }^{\circ} \mathrm{C}$, (c) four passes at $160^{\circ} \mathrm{C}$, (d) six passes at $160^{\circ} \mathrm{C}$, (e) two passes at $200{ }^{\circ} \mathrm{C}$, (f) four passes at $200{ }^{\circ} \mathrm{C}$, (g) six passes at $200{ }^{\circ} \mathrm{C}$, (h) two passes at $240{ }^{\circ} \mathrm{C}$, (i) four passes at $240{ }^{\circ} \mathrm{C}$, and (j) six passes at $240{ }^{\circ} \mathrm{C}$.

Figure 3 shows the SEM micrographs of the samples before and after the ECAP process. There were two phenomena that changed the appearance of the intermetallics: fragmentation and solution of the bulk eutectic structure, and the desolution of fine precipitation particles. In general, the appearance of the intermetallics was controlled by the deformation amount and pressing temperature during ECAP processing. In the microstructure of as-extruded $\mathrm{Mg}-6 \mathrm{Zn}$ alloy, there were some bulk eutectic structure and a significant amount of fine particles around the eutectic structure, as shown in Figure $3 \mathrm{a}$. At $160^{\circ} \mathrm{C}$, the ECAP processing not only caused eutectic deformation, distortion, and elongation, but also induced the precipitation of massive fine particles, as shown in Figure $3 \mathrm{~b}-\mathrm{d}$. However, when ECAP was performed at the higher temperature of $200^{\circ} \mathrm{C}$, because of the improvement in zinc solubility, the amount of both broken eutectics and precipitates decreased, compared with that of ECAP at $160^{\circ} \mathrm{C}$, as show in Figure 3e-g. When processed at $240^{\circ} \mathrm{C}$, with an increasing number of ECAP passes, these fine precipitates disappeared completely except for the small amount of dissolved broken eutectics. Through observing the enlarged area in the SEM image, we found the edge of these residue dispersive intermetallics were smooth, likely due to the dissolution of broken eutectic during ECAP, as shown in Figure $3 \mathrm{~h}-\mathrm{j}$.
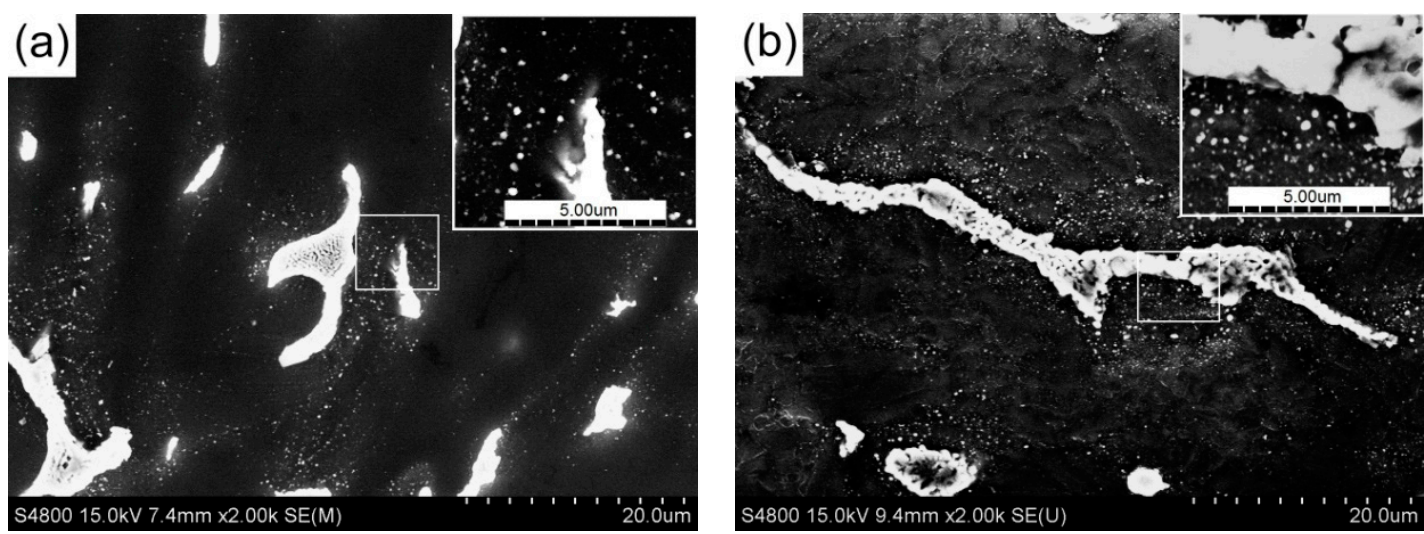

Figure 3. Cont. 

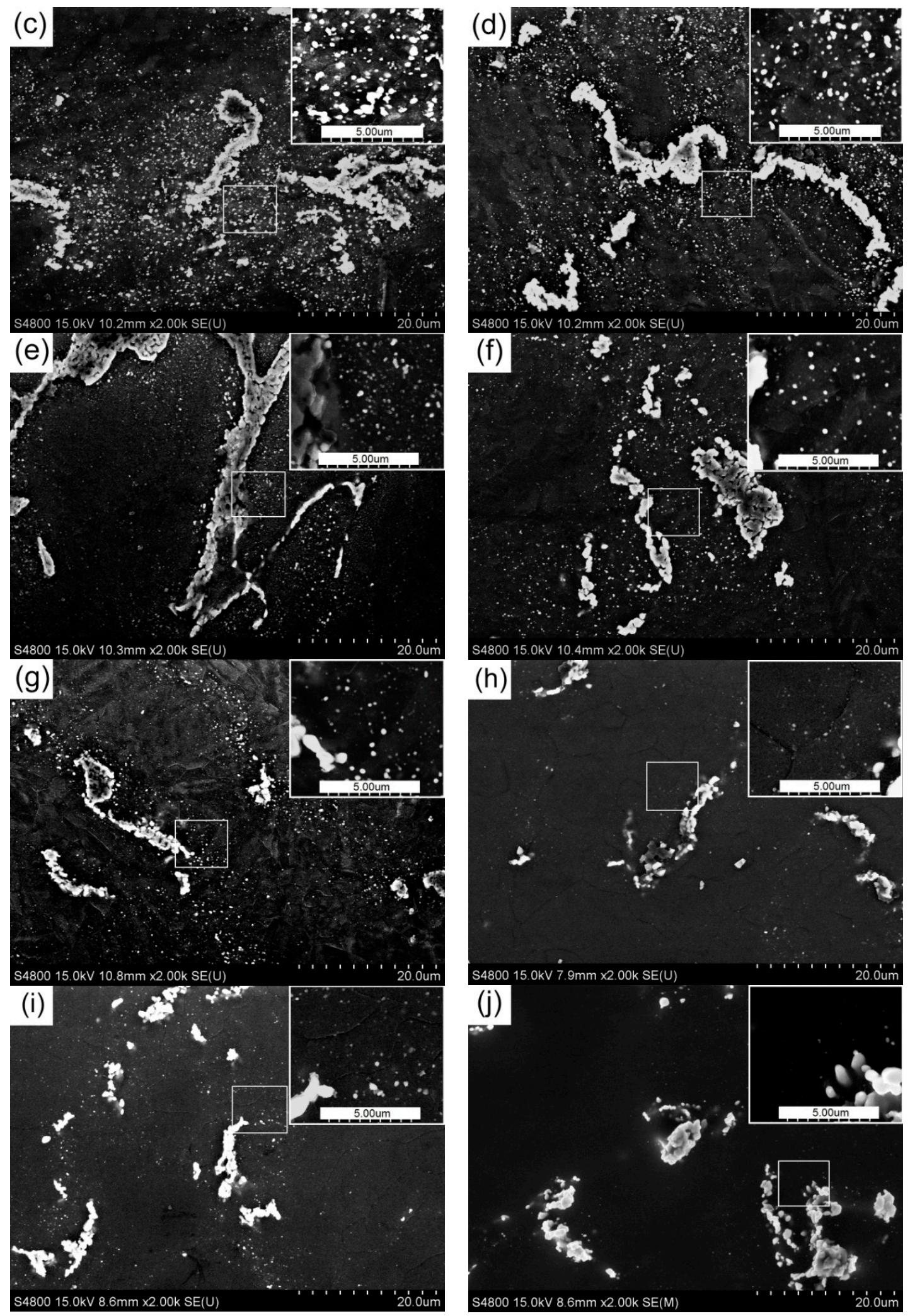

Figure 3. Scanning electron microscopy (SEM) micrographs of Mg-6Zn alloys: (a) as-extruded, and after undergoing ECAP for $(\mathbf{b})$ two passes at $160{ }^{\circ} \mathrm{C}$, (c) four passes at $160{ }^{\circ} \mathrm{C}$, (d) six passes at $160{ }^{\circ} \mathrm{C},(\mathbf{e})$ two passes at $200{ }^{\circ} \mathrm{C}$, (f) four passes at $200{ }^{\circ} \mathrm{C}$, (g) six passes at $200{ }^{\circ} \mathrm{C},(\mathbf{h})$ two passes at $240{ }^{\circ} \mathrm{C}$, (i) four passes at $240{ }^{\circ} \mathrm{C}$, and (j) six passes at $240{ }^{\circ} \mathrm{C}$. 


\subsection{Precipitate Behavior}

Figure 4 shows the XRD pattern of the as-extruded and ECAP Mg-6Zn alloy. The as-extruded $\mathrm{Mg}-6 \mathrm{Zn}$ alloy showed only the peaks of $\alpha-\mathrm{Mg}$, as shown in Figure $4 \mathrm{a}$. The XRD curve of the ECAP alloy for two passes at $160^{\circ} \mathrm{C}$ was similar to that of the as-extruded alloy. However, through slow scanning within a $2 \theta$ angle of $40^{\circ}$ to $42^{\circ}$, we found several weak diffraction peaks of the $\mathrm{MgZn}_{2}$ phase, as shown in window No. 1 of Figure $4 \mathrm{~b}$. The same approach was used to analyze the specimen processed by four passes, as shown in window No. 2 of Figure $4 b$, in which a diffraction peak located in the $2 \theta$ angle near $41^{\circ}$ decomposed into several peaks belonging to the $M g Z n_{2}$ phase and $\mathrm{Mg}_{4} \mathrm{Zn}_{7}$ phase. Processed by six passes, the intensity of the diffraction peaks of the $\mathrm{Mg}_{4} \mathrm{Zn}_{7}$ phase and $\mathrm{MgZn} \mathrm{n}_{2}$ phase increased sharply, as shown in Figure 4 b. When the ECAP temperature was $200{ }^{\circ} \mathrm{C}$ or $240{ }^{\circ} \mathrm{C}$, both the $\mathrm{Mg}_{4} \mathrm{Zn}_{7}$ and $\mathrm{MgZn}$ 2 phases were revealed in the XRD pattern, and their diffraction intensity rose with increasing numbers of ECAP passes, as shown in Figure 4c,d. From the SEM images, a large number of precipitates appeared after two passes of ECAP at $160^{\circ} \mathrm{C}$, as shown in Figure $3 \mathrm{~b}-\mathrm{d}$, which showed weak diffraction peaks due to low crystallinity. With increasing ECAP processing time, the crystallization of the precipitates increased.

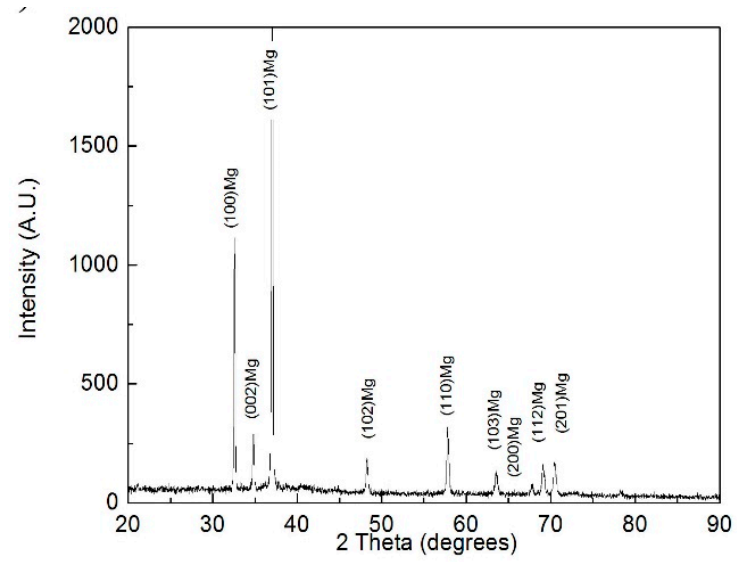

(a)

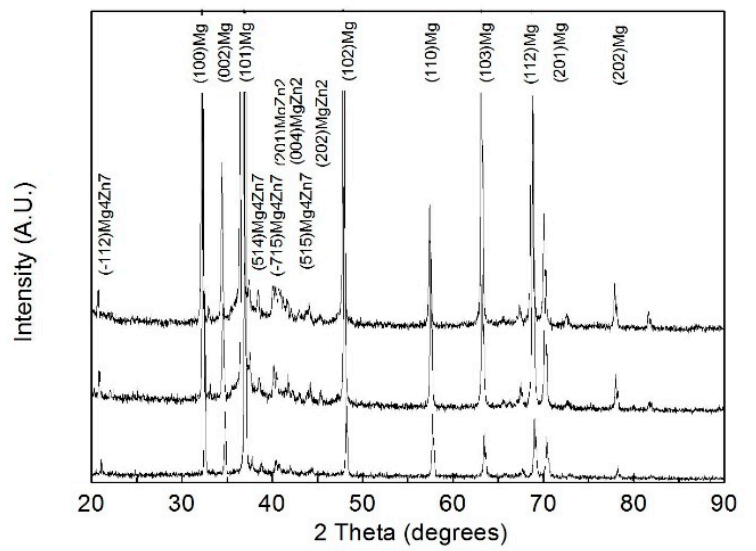

(c)

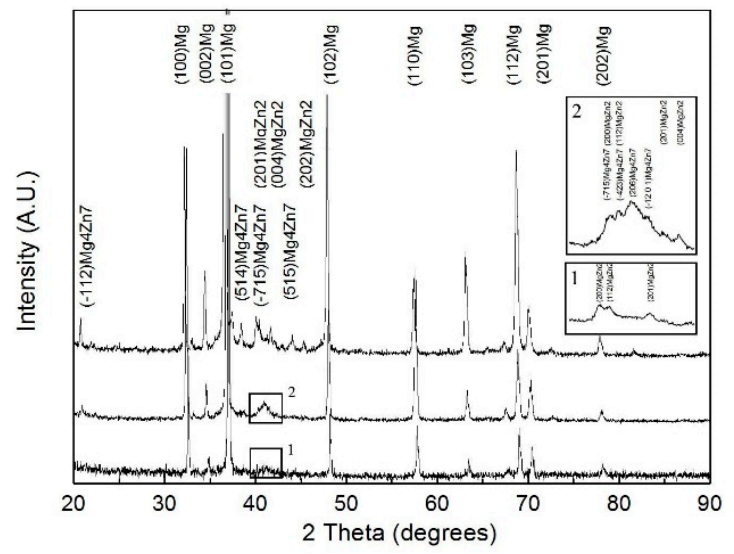

(b)

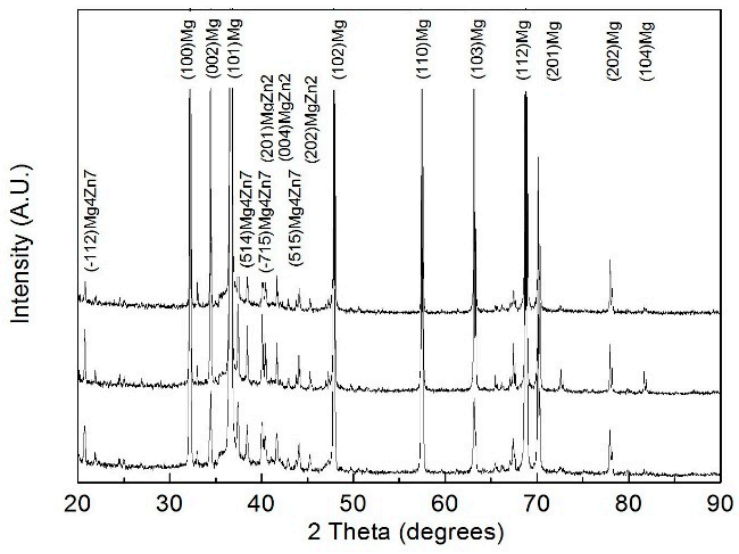

(d)

Figure 4. X-ray diffraction (XRD) patterns of Mg-6Zn: (a) as-extruded, and ECAP at (b) $160{ }^{\circ} \mathrm{C}$, (c) $200{ }^{\circ} \mathrm{C}$, and (d) $240{ }^{\circ} \mathrm{C}$.

The SEM observations and XRD results suggested that ECAP induced the precipitation of $\mathrm{Mg}_{4} \mathrm{Zn}_{7}$ and $\mathrm{MgZn}_{2}$. To further study the precipitation behavior of $\mathrm{Mg}-6 \mathrm{Zn}$ alloy during ECAP, TEM, and selected area electron diffraction (SAED) were used to determinate the morphology and structure of the intermetallics. After ECAP processing for six passes at $160{ }^{\circ} \mathrm{C}$, the aggregation of irregularly shaped particles with diameter of $0.5-1 \mu \mathrm{m}$ was transformed from the broken eutectic 
structure, around which a large number of fine particles was distributed, as shown in Figure 5a. These fine particles were spherical or ellipsoid in shape and from 10 to 100 nanometers in diameter, as shown in Figure 5b. The irregularly-shaped particles were identified as $\mathrm{Mg}_{4} \mathrm{Zn}_{7}$ phase and the finer particles were identified as $\mathrm{MgZn}_{2}$ by indexing the SAED pattern. These fine particles, varying in size, were located in grains and along grain boundaries. When processed for six passes at $200{ }^{\circ} \mathrm{C}$, the assembled larger particles became regular and smooth in shape, which were also indexed as the $\mathrm{Mg}_{4} \mathrm{Zn}_{7}$ phase by SAED, as shown in Figure 5c. By contrast, the concentration of fine particles distributed in the matrix decreased, as shown in Figure 5d. After six passes of ECAP at $240{ }^{\circ} \mathrm{C}$, the larger $\mathrm{Mg}_{4} \mathrm{Zn}_{7}$ particles eventually became spherical, as shown in Figure 5e, whereas the finer $\mathrm{MgZn}_{2}$ particles became increasingly sparse, as shown in Figure $5 \mathrm{f}$. The $\mathrm{Mg}_{4} \mathrm{Zn}_{7}$ particles were $0.5-1 \mu \mathrm{m}$ in diameter and $\mathrm{MgZn} 2$ particles were about $100 \mathrm{~nm}$.
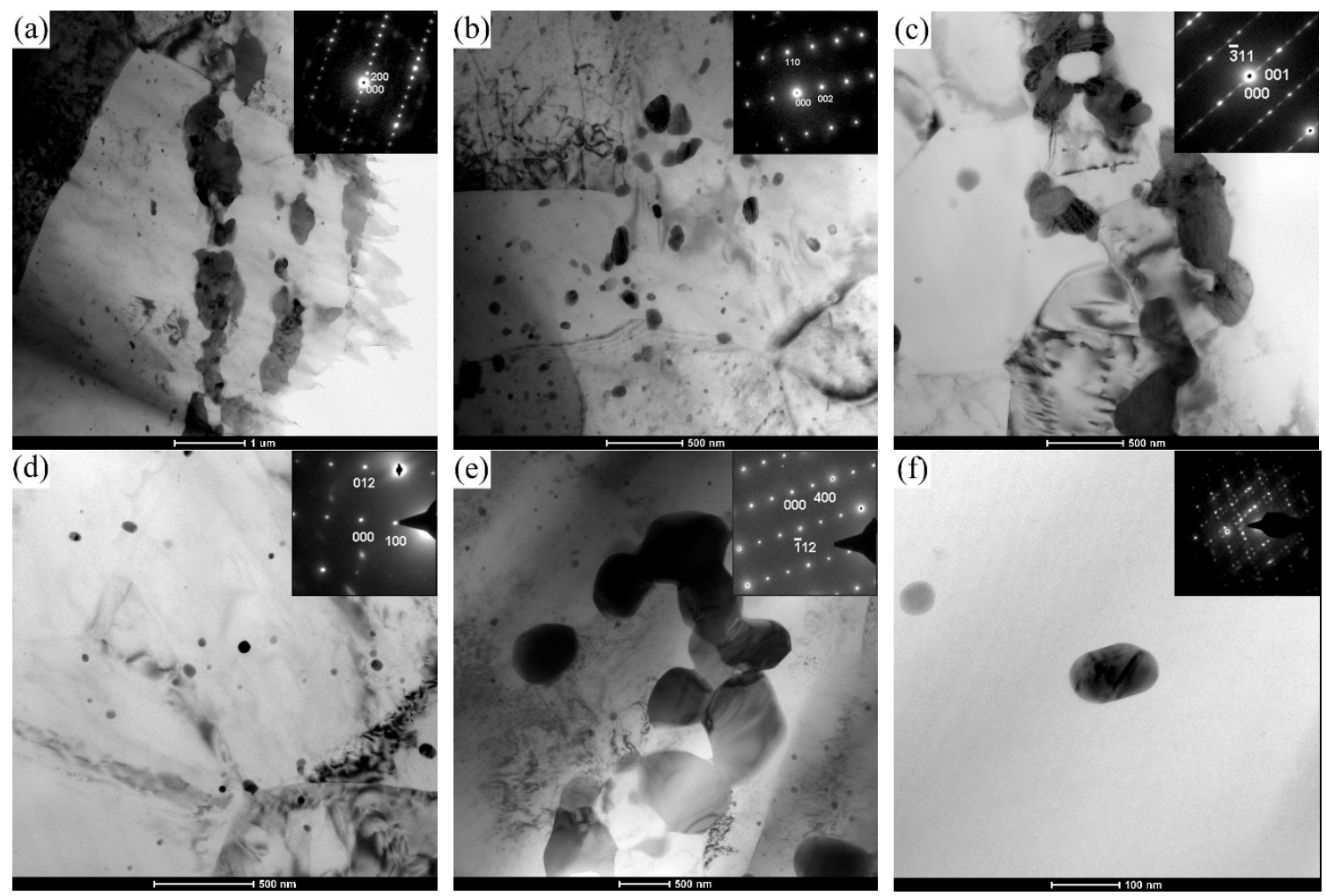

Figure 5. Transmission electron microscopy (SEM) micrographs of Mg-6Zn alloy processed by ECAP for six passes $(\mathbf{a}, \mathbf{b})$ at $160{ }^{\circ} \mathrm{C},(\mathbf{c}, \mathbf{d})$ at $200^{\circ} \mathrm{C}$, and $(\mathbf{e}, \mathbf{f})$ at $240{ }^{\circ} \mathrm{C}$.

\section{Discussion}

\subsection{Effects of ECAP on the Mechanical Properties of Mg-6Zn Alloy}

The results of the room temperature tensile test showed that the strengths could not be continuously improved by increasing deformation. At $160^{\circ} \mathrm{C}$, in the beginning of ECAP deformation, the refinement of the microstructure and the formation of massive precipitates caused strengths to increase. However, there was no obvious change in microstructure when further plastic deformation was performed (as shown in Figure 2c,d), which could explain why the strengths roughly remained unchanged in the subsequent ECAP deformation. At above $200{ }^{\circ} \mathrm{C}$, the strengths increased first and then fell with increasing ECAP passes. By comparing the microstructure and XRD patterns, we found that the diffraction peaks intensity of the precipitates increased and the precipitate particles grew in the alloy that underwent ECAP at $200^{\circ} \mathrm{C}$ and $240{ }^{\circ} \mathrm{C}$. At $200^{\circ} \mathrm{C}$, the precipitation induced by SPD accompanied by the refinement of grains improved the strength. Then, the fine precipitates either grew or dissolved in the matrix but the coarse particles were reserved in subsequent deformation 
under the Ostwald ripening effect, which reduced strengthening of the precipitation [16,17]. At the higher temperature of $240^{\circ} \mathrm{C}$, the decreasing strengths were attributed to the obvious dissolution of precipitates and grain growth, although the grains were also refined after ECAP. Yuan et al. [18] studied the effect of heat treatment and deformation temperature on the mechanical properties of ECAP ZK60 alloy, and found that the strength increased with reducing ECAP processing temperature. The authors attributed it to precipitation hardening since more fine metastable $\mathrm{MgZn}$ 2 phase precipitated at lower temperatures.

Besides grain size and precipitates, texture plays an important role on the mechanical properties. Due to texture softening, AZ31B alloy after ECAP via route $\mathrm{B}_{\mathrm{C}}$ at $200{ }^{\circ} \mathrm{C}$ exhibited a lower strength than the un-ECAP specimen [19]. The strength of ZK60 alloy decreased after four passes of ECAP at $240{ }^{\circ} \mathrm{C}$ compared to the as-received alloy, which was also attributed to texture softening [20]. In the present study, the strength of the sample after four passes of ECAP processing at both $200{ }^{\circ} \mathrm{C}$ and $240{ }^{\circ} \mathrm{C}$ was lower than the as-extruded sample, suggesting that texture softening played an important role. However, the strength of the sample after four passes of ECAP processing at $160{ }^{\circ} \mathrm{C}$ increased, although texture softening still occurred, which may be related to precipitation hardening resulting from more fine precipitates. Thus, the mechanical properties of the ECAP Mg-6Zn alloy was determined by a combination of grain refinement strengthening, precipitation hardening, and texture softening. Further study is needed to clarify their effect at different temperatures.

\subsection{Formation Mechanism of Inhomogeneous Grain Structure in Mg-6Zn Alloy during ECAP}

The experimental results indicated that the fine grains of the bi-modal grain structure mixed with a significant amount of fine precipitates distributed near the eutectic structure. Since a number of precipitates produced in the process of ECAP depend on the solute concentration in the local region and deformation temperature, which determined the saturated solubility of zinc and precipitation nucleation rate. The precipitates chiefly concentrated near the eutectic structure, which was also the zinc-rich region, or the supersaturated solid solution. In addition, these fine particles acted as strong obstacles to the dislocation movement and increased the dislocation density in the subsequent deformation process. Conversely, the dislocations and grain boundary could be not only the nucleation sites for the secondary phase but also for the diffusion channels for solute atoms during precipitation. The fine grains among the bi-modal grain structure formed and remained stable under the combination of dynamic recrystallization and the pinning effect of the fine precipitates on grain boundary. However, the coarse grains primarily formed in the zinc-poor region away from the eutectic structure due to the absence of precipitates. In a previous study, the bi-modal or multi-modal grain structure in the single-phase microstructure was due to the dynamic recrystallization under inhomogeneous deformation, which could transform into a homogeneous grain structure with increasing strain $[15,21]$. In this work, the inhomogeneous grain structure remained after six passes ECAP at $160{ }^{\circ} \mathrm{C}$ and $200{ }^{\circ} \mathrm{C}$, as shown in Figures $2 \mathrm{~d}$ and $2 \mathrm{~g}$, respectively. However, there was no appearance of a bi-modal grain structure in the microstructure of the sample processed at $240{ }^{\circ} \mathrm{C}$, as shown in Figure $2 \mathrm{j}$. Thus, unlike the single-phase microstructure, the essential reason for the formation of the bi-modal grain structure containing fine precipitation with inhomogeneous precipitate distribution was further attributed to the inhomogeneous distribution of the solute.

\subsection{Precipitation Behavior of the Intermetallic Phase in the Mg-6Zn during ECAP}

In previous reports, the $\mathrm{Mg}_{7} \mathrm{Zn}_{3}\left(\mathrm{Mg}_{51} \mathrm{Zn}_{20}\right)$ phase in the eutectic structure transformed into $\mathrm{MgZn}_{2}$ phase or $\mathrm{Mg}_{4} \mathrm{Zn}_{7}$ phase during SPD [10,11,14]. In addition, the rod-like and plate-like precipitates formed by aging treatment in many $\mathrm{Mg}-\mathrm{Zn}$ based alloys were determined to be either $\mathrm{Mg}_{4} \mathrm{Zn}_{7}$ phase, $\mathrm{MgZn}_{2}$ phase, or both [22-27]. These experimental phenomena revealed that the source of $\mathrm{MgZn}_{2}$ phase or $\mathrm{Mg}_{4} \mathrm{Zn}_{7}$ phase was not unique. Xie et al. [28] investigated the stability and elastic properties of $\mathrm{MgZn}_{2}$ and $\mathrm{Mg}_{4} \mathrm{Zn}_{7}$ using first-principles calculations and they found that the relative stability of $\mathrm{MgZn}_{2}$ and $\mathrm{Mg}_{4} \mathrm{Zn}_{7}$ was dependent on their composition and temperature. 
In this study, after processing by ECAP at $160{ }^{\circ} \mathrm{C}$, the $\mathrm{MgZn}$, phase was the main new phase after two passes, whereas the $\mathrm{Mg}_{4} \mathrm{Zn}_{7}$ phase appeared after four passes of ECAP. With ECAP processing at $160{ }^{\circ} \mathrm{C}$, the precipitation of $\mathrm{MgZn}$ reduced the zinc concentration in the matrix and then promoted the formation of the $\mathrm{Mg}_{4} \mathrm{Zn}_{7}$ phase with a lower $\mathrm{Zn} / \mathrm{Mg}$ formation ratio in subsequent deformation. At higher temperatures, the precipitation and phase transformation accelerated and the two intermetallic compounds formed quickly. In summary, the diversity of precipitates in $\mathrm{Mg}-\mathrm{Zn}$-based alloys is the result of the heterogeneity of the microstructure and the variability of the solute concentration.

\section{Conclusions}

The mechanical properties and microstructure evolution of the Mg-6 wt \% Zn alloy during multi-pass ECAP at temperatures of $160{ }^{\circ} \mathrm{C}, 200{ }^{\circ} \mathrm{C}$, and $240{ }^{\circ} \mathrm{C}$ were systematically investigated. The main conclusions are summarized as follows:

(1) ECAP was effective for grain refinement in $\mathrm{Mg}-6 \mathrm{Zn}$ alloy. A bi-modal grain structure formed at low temperatures, which was stable during ECAP at $160^{\circ} \mathrm{C}$ and $200^{\circ} \mathrm{C}$.

(2) $\mathrm{MgZn}_{2}$ phase and $\mathrm{Mg}_{4} \mathrm{Zn}_{7}$ phase were generated from the $\mathrm{Mg}-6 \mathrm{Zn}$ alloy during the ECAP process.

(3) The mechanical properties increased after two passes of ECAP. During further deformation, the strengths nearly remained constant when processed at $160{ }^{\circ} \mathrm{C}$ but decreased when processed at $200{ }^{\circ} \mathrm{C}$ and $240{ }^{\circ} \mathrm{C}$.

(4) The mechanical properties of the ECAP Mg-6Zn alloy was determined by a combination of grain refinement strengthening, precipitation hardening, and texture softening.

Author Contributions: J.Y. and K.Y. conceived and designed the experiments; Z.Q. and K.Y. performed the experiments; J.Y. analyzed the data; J.Y. and K.Y. wrote the paper. All authors have discussed the results, read and approved the final manuscript.

Acknowledgments: This research was funded by [the national natural science foundation of China] grant number [51501039] and [51301151] and by [the natural science foundation of Jiangsu province] grant number [BK20151411] and [BK20160869].

Conflicts of Interest: The authors declare no conflict of interest.

\section{References}

1. Zheng, Y.F.; Gu, X.N.; Witte, F. Biodegradable Metals. Mater. Sci. Eng. R Rep. 2014, 77, 1-34. [CrossRef]

2. Manivasagam, G.; Suwas, S. Biodegradable $\mathrm{Mg}$ and $\mathrm{Mg}$ Based Alloys for Biomedical Implants. Mater. Sci. Technol. 2014, 30, 515-520. [CrossRef]

3. Chen, Y.; Yan, J.; Wang, Z.; Yu, S.; Wang, X.; Yuan, Z.; Zhang, X.; Zhao, C.; Zheng, Q. In vitro and in vivo corrosion measurements of Mg-6Zn alloys in the bile. Mater. Sci. Eng. C Mater. Biol. Appl. 2014, 42, 116-123. [CrossRef] [PubMed]

4. Jang, Y.; Tan, Z.; Jurey, Z.; Xu, Z.; Dong, Z.; Collins, B.; Yun, Y.; Sankar, J. Understanding corrosion behavior of $\mathrm{Mg}-\mathrm{Zn}-\mathrm{Ca}$ alloys from subcutaneous mouse model: Effect of $\mathrm{Zn}$ element concentration and plasma electrolytic oxidation. Mater. Sci. Eng. C 2015, 48, 28-40. [CrossRef] [PubMed]

5. Langdon, T.G. Twenty-five years of ultrafine-grained materials: Achieving exceptional properties through grain refinement. Acta Mater. 2013, 61, 7035-7059. [CrossRef]

6. Ma, A.B.; Jiang, J.H.; Saito, N.; Shigematsu, I.; Yuan, Y.C. Improving both strength and ductility of a Mg alloy through a large number of ECAP passes. Mater. Sci. Eng. A 2009, 513-514, 122-127. [CrossRef]

7. Xu, C.; Furukawa, M.; Horita, Z.; Langdon, T.G. The evolution of homogeneity and grain refinement during equal-channel angular pressing: A model for grain refinement in ECAP. Mater. Sci. Eng. A 2005, 398, 66-76. [CrossRef]

8. Lin, H.K.; Huang, J.C.; Langdon, T.G. Relationship between texture and low temperature superplasticity in an extruded AZ31 Mg alloy processed by ECAP. Mater. Sci. Eng. A 2005, 402, 250-257. [CrossRef] 
9. Figueiredo, R.B.; Langdon, T.G. Principles of grain refinement and superplastic flow in magnesium alloys processed by ECAP. Mater. Sci. Eng. A 2009, 501, 105-114. [CrossRef]

10. Song, Y.W.; Han, E.H.; Shan, D.Y.; Yim, C.D.; You, B.S. The effect of Zn concentration on the corrosion behavior of Mg-xZn alloys. Corros. Sci. 2012, 60, 238-245. [CrossRef]

11. Gao, J.H.; Guan, S.K.; Ren, Z.W.; Sun, Y.F.; Zhu, S.J.; Wang, B. Homogeneous corrosion of high pressure torsion treated $\mathrm{Mg}-\mathrm{Zn}-\mathrm{Ca}$ alloy in simulated body fluid. Mater. Lett. 2011, 60, 691-693. [CrossRef]

12. Ying, T.; Zheng, M.Y.; Li, Z.T.; Qiao, X.G.; Xu, S.W. Thermal conductivity of as-cast and as-extruded binary Mg-Zn alloys. J. Alloys Compd. 2015, 621, 250-255. [CrossRef]

13. Tong, L.B.; Zheng, M.Y.; Hu, X.S.; Wu, K.; Xu, S.W.; Kamado, S.; Kojima, Y. Influence of ECAP routes on microstructure and mechanical properties of Mg-Zn-Ca alloy. Mater. Sci. Eng. A 2010, 527, 4250-4256. [CrossRef]

14. Yan, K.; Sun, Y.S.; Bai, J.; Xue, F. Microstructure and mechanical properties of ZA62 Mg alloy by equal-channel angular pressing. Mater. Sci. Eng. A 2011, 528, 1149-1153. [CrossRef]

15. Figueiredo, R.B.; Langdon, T.G. Grain refinement and mechanical behavior of a magnesium alloy processed by ECAP. J. Mater. Sci. 2010, 45, 4827-4836. [CrossRef]

16. Zhao, Z.D.; Chen, Q.; Wang, Y.B.; Shu, D.Y. Effect of predeformation on semi-solid microstructure of ZK60+RE magnesium alloy. Trans. Nonferrous Met. Soc. China 2009, 19, 535-539. [CrossRef]

17. Luo, S.J.; Chen, Q.; Zhao, Z.D. An investigation of microstructure evolution of RAP processed ZK60 magnesium alloy. Mater. Sci. Eng. A 2009, 501, 146-152. [CrossRef]

18. Yuan, Y.C.; Ma, A.B.; Gou, X.F.; Jiang, J.H.; Arhin, G.; Song, D.; Liu, H. Effect of heat treatment and deformation temperature on the mechanical properties of ECAP processed ZK60 magnesium alloy. Mater. Sci. Eng. A 2016, 677, 125-132. [CrossRef]

19. Ding, S.X.; Lee, W.T.; Chang, C.P.; Chang, L.W.; Kao, P.W. Improvement of strength of magnesium alloy processed by equal channel angular extrusion. Scr. Mater. 2008, 59, 1006-1009. [CrossRef]

20. He, Y.B.; Pan, Q.L.; Qin, Y.J.; Liu, X.Y.; Li, W.B.; Chiu, Y.L.; Chen, J.J. Microstructure and mechanical properties of ZK60 alloy processed by two-step equal channel angular pressing. J. Alloys Compd. 2010, 492, 605-610. [CrossRef]

21. Valle, J.A.; Ruano, O.A. Superplasticity in a magnesium alloy prepared with bimodal grain size distributions developed by dynamic recrystallisation. Mater. Lett. 2008, 62, 3391-3394. [CrossRef]

22. Mendis, C.L.; Oh-ishi, K.; Kawamura, Y.; Honma, T.; Kamado, S.; Hono, K. Precipitation-Hardenable Mg-2.4 Zn-0.1 Ag-0.1 Ca-0.16 Zr (at.\%) Wrought Magnesium Alloy. Acta Mater. 2009, 57, 749-760. [CrossRef]

23. Mendis, C.L.; Oh-ishi, K.; Hono, K. Enhanced age hardening in a Mg-2.4 at.\% Zn alloy by trace additions of Ag and Ca. Scr. Mater. 2007, 57, 485-488. [CrossRef]

24. Gao, X.; Nie, J.F. Characterization of strengthening precipitate phases in a Mg-Zn alloy. Scr. Mater. 2007, 56, 645-648. [CrossRef]

25. Gao, X.; Nie, J.F. Structure and thermal stability of primary intermetallic particles in an $\mathrm{Mg}-\mathrm{Zn}$ casting alloy. Scr. Mater. 2007, 57, 655-658. [CrossRef]

26. Singh, A.; Tsai, A.P. Structural characteristics of $\beta 1^{\prime}$ precipitates in Mg-Zn-based alloys. Scr. Mater. 2007, 57, 941-944. [CrossRef]

27. Wei, L.Y.; Dunlop, G.L.; Westengen, H. The intergranular microstructure of cast Mg-Zn and Mg-Zn-rare earth alloys. Metall. Mater. Trans. A 1995, 26A, 1947-1955. [CrossRef]

28. Xie, Y.P.; Wang, Z.Y.; Hou, Z.F. The phase stability and elastic properties of $\mathrm{MgZn}_{2}$ and $\mathrm{Mg}_{4} \mathrm{Zn}_{7}$ in $\mathrm{Mg}-\mathrm{Zn}$ alloys. Scr. Mater. 2013, 68, 495-498. [CrossRef]

(C) 2018 by the authors. Licensee MDPI, Basel, Switzerland. This article is an open access article distributed under the terms and conditions of the Creative Commons Attribution (CC BY) license (http://creativecommons.org/licenses/by/4.0/). 